\title{
Trophic relationships between the farmed pearl oyster Pinctada margaritifera and its epibionts revealed by stable isotopes and feeding experiments
}

\author{
Élise Lacoste ${ }^{1}$, Patrick Raimbault ${ }^{2}$, Mireille Harmelin-Vivien ${ }^{2}$, \\ Nabila Gaertner-Mazouni ${ }^{1, *}$ \\ ${ }^{1}$ UMR 241-EIO, Université de la Polynésie Française, 98702 Faa'a, Tahiti, French Polynesia \\ ${ }^{2}$ Aix Marseille Université, CNRS/INSU/IRD, Université de Toulon, Institut Méditerranéen d'Océanologie (MIO), \\ 13331 Marseille, France
}

\begin{abstract}
Bivalve cultures support a host of epibionts, mainly suspension feeders, which can compete for food resources with the cultivated bivalves. However, the magnitude of interspecific competition for food in bivalve aquaculture settings remains inconclusive, especially in tropical areas. We investigated the interactions for food between the farmed pearl oyster Pinctada margaritifera and its epibionts, using stable isotope analysis and feeding experiments. Inter- and intraspecific variations of $\delta^{13} \mathrm{C}$ and $\delta^{15} \mathrm{~N}$ stable isotope ratios (SIRs) were determined for oysters in the presence or absence of epibionts. The diet of the most abundant epibionts, Herdmania momus and Didemnum sp., was specified using isotope measurements and flow cytometry during feeding experiments, to determine the main phytoplankton groups consumed by these ascidians in natural conditions. The absence of intraspecific variation in SIRs among oysters with or without epibionts suggested that the diet of $P$. margaritifera was not affected by the presence of epibionts, indicating a reduced diet overlap and no food limitation. The $\delta^{13} \mathrm{C}$ signature of ascidians $(-21 \%)$ was lower than that of oysters $(-18 \%)$, indicating a difference in organic matter sources ingested by these filter feeders despite receiving the same food mixture. While the main carbon source of oysters came from large particulate organic matter $(\mathrm{POM})>20 \mu \mathrm{m}$, our results showed that the diet of ascidians mainly came from smaller particles (POM $<20 \mu \mathrm{m})$ and reflects the composition of ambient water (mainly picophytoplankton $<2 \mu \mathrm{m}$ ), which confirmed their lack of food selectivity. In the studied conditions, food competition between oysters and epibionts, specifically ascidians, was not a limiting factor, in spite of a diet overlap for nanophytoplankton.
\end{abstract}

KEY WORDS: Ascidian · Biofouling $\cdot$ Trophic interactions $\cdot$ Stable isotope $\cdot$ Flow cytometry

\section{INTRODUCTION}

An inherent issue with the development of bivalve aquaculture is biofouling (Cranford et al. 2003, Rius et al. 2011, Lacoste \& Gaertner-Mazouni 2015). Both submerged rearing structures and bivalve shells offer settlement substrates for many epibiont species

*Corresponding author: nabila.gaertner-mazouni@upf.pf
(Guenther \& DeNys 2006, Woods et al. 2012). Biofouling is generally considered a plague for aquaculture (Willemsen 2005, Adams et al. 2011), especially because filter feeder epibionts (e.g. ascidians, bivalves) may compete for food with reared bivalves (Claereboudt et al. 1994, Lopez et al. 2000, Pit \& Southgate 2003). Although such competition can

(C) The authors 2016. Open Access under Creative Commons by Attribution Licence. Use, distribution and reproduction are unrestricted. Authors and original publication must be credited. 
cause severe damage to commercial production (cf. review by Fitridge et al. 2012), few authors have compared the use of available food resources by epibionts and bivalves to assess the extent to which they compete for food or might share resources. Some authors have reported competition between mussels and ascidians (Petersen 2007, Daigle \& Herbinger 2009, Sievers et al. 2013), while others have highlighted possible food resource partitioning (Riera et al. 2002, Kang et al. 2009). Lesser et al. (1992) and Petersen (2007) emphasized that competition between filter feeders is low when food is diverse and abundant. Other authors have suggested complementary and positive trophic interactions between filter feeders (Mook 1981, Arakawa 1990, Mazouni et al. 2001).

In French Polynesia, pearl oyster rearing structures are immersed throughout the year, providing artificial structure that facilitates the establishment of numerous epibionts. The main epibionts are bivalves, ascidians, bryozoans, and sponges (Lacoste 2014), all belonging to the guild of suspension feeders. In the oligotrophic lagoons of French Polynesia, the phytoplankton is dominated by pico-sized particles (Charpy \& Blanchot 1998, Dupuy et al. 2009), which are considered to be not directly available to pearl oysters (Loret et al. 2000, Fournier et al. 2012). In these systems, the food resource is thus limited, and biofouling development could represent a serious constraint for pearl oyster production. In this context, it is essential to clarify the trophic relationships between the different filter feeders in farmed areas (i.e. pearl oysters and epibionts).

The aim of this study was to investigate the trophic relationships between the farmed pearl oyster Pinctada margaritifera and its epibionts, especially 2 widespread ascidians in French Polynesia, Herdmania momus (solitary ascidian) and Didemnum sp. (colonial ascidian), by coupling stable isotope analysis and feeding experiments. Stable isotope analysis has been increasingly used over the last decade to identify the diet of organisms (Fry 2006) and provides new insights into the trophic relationships between reared bivalves and their potential competitors (Dubois et al. 2007, Kang et al. 2009, Lefebvre et al. 2009). The carbon and nitrogen isotopic composition of consumer tissues depends on (1) the ratios of ${ }^{13} \mathrm{C}$ to ${ }^{12} \mathrm{C}$ (expressed as $\delta^{13} \mathrm{C}$ ) and ${ }^{15} \mathrm{~N}$ to ${ }^{14} \mathrm{~N}$ (expressed as $\delta^{15} \mathrm{~N}$ ) of each food source, (2) the relative proportion of each food source assimilated, and (3) the isotopic fractionation between the food and the consumer's tissue (i.e. consumers are isotopically enriched compared to their prey). Thus, $\delta^{15} \mathrm{~N}$ and $\delta^{13} \mathrm{C}$ give information on the trophic level of a consumer and the origin of its food sources, respectively. From these properties, we investigated the interspecific similarities of $\delta^{13} \mathrm{C}$ and $\delta^{15} \mathrm{~N}$ of pearl oysters and ascidians that could be seen as an indicator of competition between these organisms (Decottignies et al. 2007, Dubois et al. 2007, Miranda \& Perissinotto 2012). Interspecific competition for food may induce variability in the diet of organisms in the presence of competitors (Haken \& Batzli 1996). We thus measured $\delta^{13} \mathrm{C}$ and $\delta^{15} \mathrm{~N}$ of pearl oysters in the presence or absence of a whole community of epibionts, considering that differences could be interpreted as evidence of trophic competition (Kang et al. 2009, Yakovis et al. 2012). In addition, flow cytometry was used to identify the food items retained by ascidians under natural conditions, and to clarify their feeding strategy (clearance rate, retention efficiency). The combination of isotope analysis and cytometry has been successfully used to assess particle feeding of sponges (Topçu et al. 2010), but to our knowledge, this is the first time that coupled flow cytometry and stable isotopes have been used to investigate the trophic relationships between reared bivalves and epibionts.

\section{MATERIALS AND METHODS}

\section{Sampling strategy}

The main monitoring experiment was carried out on Mangareva Island during 20 mo to determine the trophic relationships between pearl oysters and their filter feeder epibionts during biofouling development. An additional sampling was carried out in the Ahe Atoll, where pearl farming is well developed and biofouling may represent considerable biomass (Lacoste et al. 2014a).

The high island of Mangareva is located in the Gambier Archipelago, $1700 \mathrm{~km}$ southeast of Tahiti (Fig. 1). In this archipelago, 14 islands are spread over $500 \mathrm{~km}^{2}$ of a lagoon largely open to the ocean. Pearl farming in this area is highly developed, with 79 pearl farms distributed over 1260 ha in 2013 (Talvard 2015). The study site is located in the western part of the island, in Gatavake Bay (Fig. 1). In November 2011, 2 yr old pearl oysters were immersed in an area of $30 \mathrm{~m}$ depth, on longlines between 7 and $10 \mathrm{~m}$ depth in 'kangaroo nets' (Fig. 1). Pearl oysters were partitioned into 2 exper- 
Fig. 1. Geographic location of Ahe and Mangareva. Crosses show the sites where sampling took place. The photo on the right represents a kangaroo net suspended on a longline
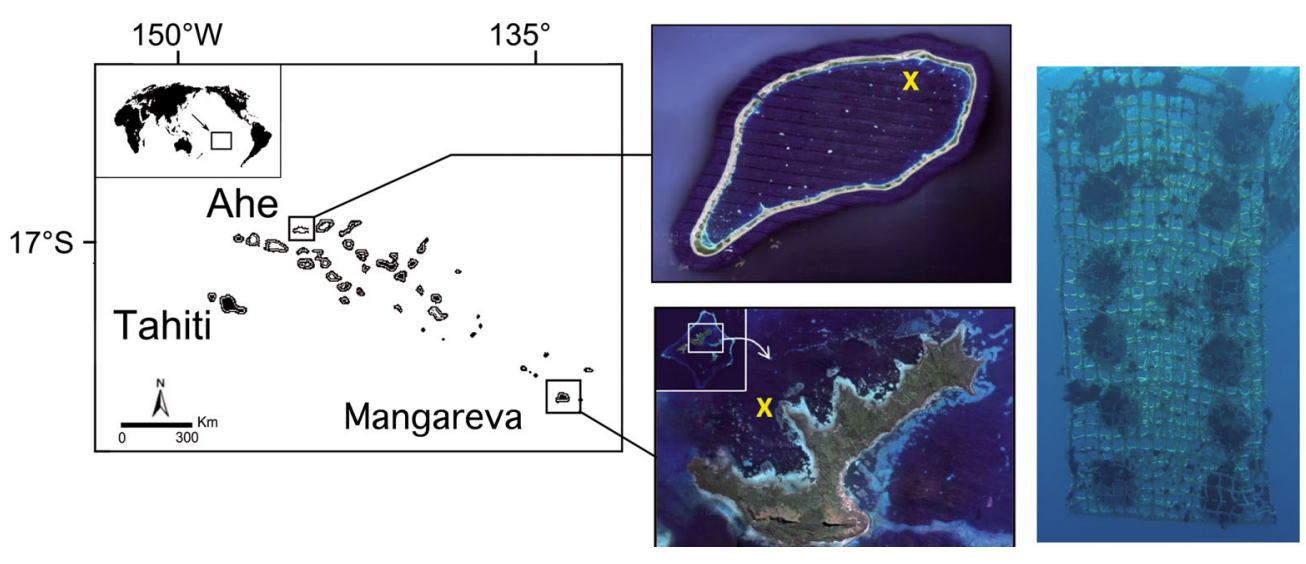

imental groups, each distributed in 4 'kangaroo nets' (12 oysters net ${ }^{-1}$ ). The first group ('clean pearl oysters') was cleaned every 3 mo as is the current practice in pearl farms, while the second group ('pearl oysters with epibionts') was never cleaned, allowing the development of a biofouling community for the entire period of the experiment. Three samplings were carried out during austral winter in May 2012 and austral summer in November 2012 and October 2013. Each time, 1 net of each treatment was sampled for biofouling characterization and stable isotope analysis of pearl oysters and ascidians. In July 2013, after 20 mo of biofouling development, the experimental groups were accidentally cleaned by the farmer. One net of each treatment was therefore sent to the laboratory for isotope analysis of organisms (pearl oysters and ascidians). Except on this date, potential food sources of pearl oysters and epibionts were sampled in the field, and feeding experiments were carried out to investigate the diet of 2 ascidians species, viz. Didemnum sp. and Herdmania momus, which were the most abundant species on the nets. During each survey in Mangareva, we measured the length and weight of pearl oysters in the 2 groups to monitor the impact of biofouling on the growth rate of pearl oysters (see Lacoste et al. 2014b for detailed results).

In addition to the monitoring in Mangareva, sampling was carried out in May 2013 in Ahe. Pearl oysters, ascidians, and food sources were collected for isotope analysis. The semi-enclosed atoll of Ahe is located more than $8^{\circ}$ latitude north of Mangareva. An active channel allows exchange with oceanic waters in its western part, and $11 \%$ of the lagoon is exploited for pearl farming. The experimental pearl farm was located in the northern part of the atoll (Fig. 1), where pearl oysters are reared on ropes and cleaned every 3 to 6 mo by the farmer.

\section{Biofouling characterization}

In Mangareva, biofouling was quantified after 6 and 12 mo of colonization from November 2011. One net of each treatment was randomly selected for biofouling analysis. Nets were partitioned into 3 subsamples on which all epibionts were collected for identification and biomass estimation (wet weight). Biomass was then calculated for an entire net.

Pearl oysters collected in Ahe came from a group that had not been cleaned during 4 mo. Using the same method as in Mangareva, epibionts were identified and the weight expressed for a rope of 12 pearl oysters (corresponding to 1 net in Mangareva).

\section{Stable isotope analysis}

For stable isotope analysis, 5 to 10 pearl oysters of each group (clean pearl oysters and pearl oysters with epibionts) were randomly collected on nets during each survey at each site. Three pools of ascidians were also collected, including 5 to $10 \mathrm{H}$. momus and several colonies of Didemnum sp., according to their abundance. Muscle tissues of pearl oysters and whole organisms of ascidians were analyzed for isotopic ratios. Tissues were thoroughly rinsed with filtered seawater $(0.2 \mu \mathrm{m})$ to prevent any contamination by shell carbonates before being freeze-dried.

In French Polynesian lagoons, the main source of food available for pearl oysters and ascidians is particulate organic matter (POM), which is mainly composed of phytoplankton. Water was sampled in the west lagoon of Mangareva and near the pearl farm in northeastern Ahe (Fig. 1), at the same depth where pearl oysters are reared (10 to $15 \mathrm{~m}$ ). POM was fractionated into 2 size classes: POM > $20 \mu \mathrm{m}$ and POM $<20 \mu \mathrm{m}$. POM > $20 \mu \mathrm{m}$ was collected using a plankton net. After removing POM $>80 \mu \mathrm{m}$ with a sieve, the 
collected matter was filtered on pre-combusted GF/F filters $\left(4 \mathrm{~h}\right.$ at $\left.500^{\circ} \mathrm{C}\right)$. For POM $<20 \mu \mathrm{m}, 20 \mathrm{l}$ of seawater were sampled using a Niskin bottle, pre-filtered with a $20 \mu \mathrm{m}$ sieve, and filtered on pre-combusted GF/F. Thus, the particle size ranged from $>20$ to $<80 \mu \mathrm{m}$ for POM $>20 \mu \mathrm{m}$ and from $>0.7$ to $<20 \mu \mathrm{m}$ for POM $<20 \mu \mathrm{m}$. Each fraction of POM was sampled in triplicate and filters were freeze-dried. In May 2012, the fraction of POM $>20 \mu \mathrm{m}$ was excluded from the analysis because of contamination of the samples.

$\mathrm{C}$ and $\mathrm{N}$ stable isotope analyses were conducted on 1 to $5 \mathrm{mg}$ of each sample. Samples were placed in tin capsules and acidified with $100 \mu \mathrm{l}$ sulfuric acid $(0.25 \mathrm{~N})$ to remove any potential residual inorganic carbon, and dried at $60^{\circ} \mathrm{C}$, following the method of Raimbault et al. (2008). The isotopic composition of carbon $\left(\delta^{13} \mathrm{C}\right)$ and nitrogen $\left(\delta^{15} \mathrm{~N}\right)$ was then measured with a stable isotope ratio (SIR) mass spectrometer (INTEGRA CN, Sercon). Carbon and nitrogen SIRs were expressed in conventional $\delta$ unit notation in relation to international standards (Vienna-PeeDee Belemnite for carbon; atmospheric $\mathrm{N}_{2}$ for nitrogen), with the formula:

$$
\left.\delta X(\%)=\left[\left(R_{\text {sample }} / R_{\text {standard }}\right)-1\right)\right] \times 10^{3}
$$

where $X={ }^{13} \mathrm{C}$ or ${ }^{15} \mathrm{~N}$, and $R$ is the corresponding ${ }^{13} \mathrm{C}:{ }^{12} \mathrm{C}$ or ${ }^{15} \mathrm{~N}:{ }^{14} \mathrm{~N}$ ratio. Analytical precision based on the standard deviation of replicates of internal standards was $0.3 \%$ o for nitrogen and $0.2 \%$ for carbon. The C:N atomic ratio of samples was calculated using carbon and nitrogen content $(\% \mathrm{C}$ and $\% \mathrm{~N})$ obtained with isotopic values. According to the filtered volume, the material collected on filters was used to estimate the quantity of particulate organic carbon (POC) and nitrogen (PON) in the water column.

Effects of time, treatment (presence vs. absence of epibionts), and group (pearl oyster vs. epibiont) on SIRs were tested using 2-way ANOVAs. Since an unbalanced design resulted from the presence/ absence of ascidians depending on the period of sampling, type II/III ANOVAs were performed (Herr 1986). All data were graphically assessed for normality and homogeneity of residuals. In the case of significant differences $(\mathrm{p}<0.05)$, a posteriori comparison of means was performed using a post hoc Tukey's test (Tukey's HSD).

\section{Feeding experiments}

The food source exploitation by ascidians was studied in Mangareva. Ascidians were collected by hand on pearl oyster nets during the 3 surveys. The experi- mental set-up consisted of 3 to 6 microcosms (see Table 5) filled with 1 to $2 \mathrm{l}$ of ambient seawater (depending on the quantity and size of organisms), to be representative of natural conditions. For each experiment, 1 microcosm with no organisms was used as a control to monitor the natural variations in phytoplankton (Coughlan 1969). Microcosms were open to prevent oxygen depletion and create natural air flow. Phytoplankton concentration was monitored in each microcosm by sampling $5 \mathrm{ml}$ every $15 \mathrm{~min}$ until half of the initial plankton concentration was reached. Samples were fixed with formalin (final concentration of $1 \%$ ) and stored at $4^{\circ} \mathrm{C}$ before being analyzed (maximum $1 \mathrm{~h}$ after sampling). The phytoplankton community was analyzed by flow cytometry, allowing discrimination of several populations simultaneously. The cytometer was a CyFlow®SL (Partec) equipped with a $488 \mathrm{~nm}$ argon laser. Calibration was done using $3 \mu \mathrm{m}$ fluorescent beads; this size was thus chosen to discriminate picophytoplankton $(<3 \mu \mathrm{m})$ from nanophytoplankton (>3 $\mu \mathrm{m}$; see Fig. 4). The signal was triggered on red fluorescence (chlorophyll a) to discriminate detritus. Phytoplankton groups were identified on the basis of their optical properties (light scattered by the cells and fluorescent signature), and their abundance was calculated using the absolute volumetric system and the FloMax ${ }^{\circledR}$ software.

Clearance rate (CR) is defined as the volume of water cleared of suspended particles per unit time $\left(\mathrm{l} \mathrm{h}^{-1}\right)$. We calculated CR according to Coughlan (1969) for the feeding experiment in incubation systems:

$$
\mathrm{CR}=V \times \frac{\log \left(C_{0}\right)-\log \left(C_{t}\right)}{\log \left(C_{0}{ }^{\prime}\right)-\log \left(C_{t}{ }^{\prime}\right)}
$$

where $V$ is the volume of the microcosm, $C_{0}$ and $C_{t}$ are the initial and final phytoplankton concentrations, respectively, and $C_{0}{ }^{\prime}$ and $C_{t}{ }^{\prime}$ are the initial and final phytoplankton concentration in controls. CR was then normalized to tissue mass and time by dividing $\mathrm{CR}$ for each ascidian by the weight (dry weight, DW, in $\mathrm{g}$ ) and time interval (h) (final $\mathrm{CR}$ in $1 \mathrm{~h}^{-1} \mathrm{~g}^{-1} \mathrm{DW}$ ). Retention efficiency (RE) of ascidians for the different planktonic groups was calculated by subtracting the initial $\left(C_{0}\right)$ and final concentration $\left(C_{t}\right)$ of phytoplankton in a microcosm:

$$
\operatorname{RE}(\%)=100 \times \frac{C_{0}-C_{t}}{C_{0}}
$$

The quantity of carbon filtered by ascidians for each phytoplankton group was calculated by multiplying CR by the carbon concentration of each group in the environment (Topçu et al. 2010). Calculations were based on the carbon content of each group 
given by Dupuy et al. (2009): $1.2 \times 10^{-7} \mu \mathrm{g} \mathrm{C}$ cell $^{-1}$ for cyanobacteria, $8.4 \times 10^{-7} \mathrm{\mu g} \mathrm{C}$ cell $^{-1}$ for picophytoplankton, and $4.7 \times 10^{-6} \mu \mathrm{g} \mathrm{C}$ cell $^{-1}$ for nanophytoplankton. The percentage of each group filtered by ascidians was then calculated.

\section{RESULTS}

\section{Biofouling development}

In Mangareva, the biofouling community was largely dominated by ascidians and showed strong temporal variations (Fig. 2). Colonization began with the settlement of the colonial ascidian Didemnum sp. on nets and pearl oyster shells (Fig. 2). After 6 mo, the nets were almost entirely covered by Didemnum sp., which declined afterwards. From 12 mo, Didemnum sp. disappeared and was replaced by the solitary ascidian Herdmania momus. The mean $( \pm$ SD) weight of epibionts on nets after 6 mo of colonization (November 2011 to May 2012) was $804 \pm 300$ g, corresponding to an accumulation rate of $134 \pm 50 \mathrm{~g}$ $\mathrm{mo}^{-1}$. After $1 \mathrm{yr}$ (November 2012), the weight of epibionts reached $980 \pm 19 \mathrm{~g}$, indicating a slowdown of the colonization between the sixth and twelfth month of monitoring (accumulation rate of $56 \pm 1 \mathrm{~g}$ $\mathrm{mo}^{-1}$ ). In Ahe, bivalves (Pinctada maculata, Isognomon sp., Saccostrea sp.) were the main epibiont species recorded. The solitary ascidian $H$. momus was present, but only a few colonial Didemnum sp. were observed. After 4 mo of colonization, the mean weight of epibionts on 12 pearl oysters (corresponding to 1 net in Mangareva) was $410 \pm 15 \mathrm{~g}$.

\section{SIRs}

C:N ratios of POM varied between 5 and 7 for the 2 size classes at both sites (Table 1). The fraction $<20 \mu \mathrm{m}$ always represented at least $97 \%$ of the total POM (PON + POC) for the 2 sites. In Mangareva, POC and PON were 2 times higher in October 2013 than in November 2012 for the fraction $<20 \mu \mathrm{m}$ and 3 times higher for the fraction $>20 \mu \mathrm{m}$. In Ahe, the POM concentration was more than twice higher than in Mangareva for the fraction $>20 \mu \mathrm{m}$. At both sites, POM $>20 \mu \mathrm{m}$ was ${ }^{13} \mathrm{C}$-enriched compared with the smallest fraction (Fig. 3).

Mean SIRs of pearl oysters varied between 3.5 and $5.5 \%$ for nitrogen and between -18.3 and $-17.8 \%$ for carbon (Fig. 3, Table 2). $\delta^{15} \mathrm{~N}$ of ascidians varied

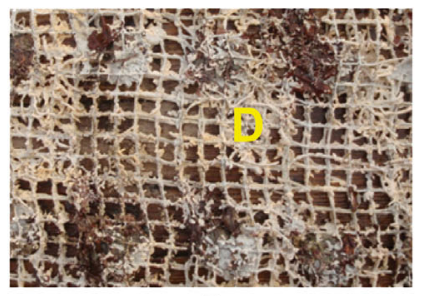

6

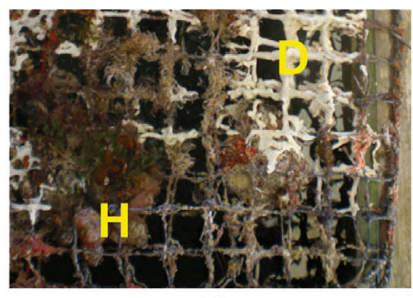

12

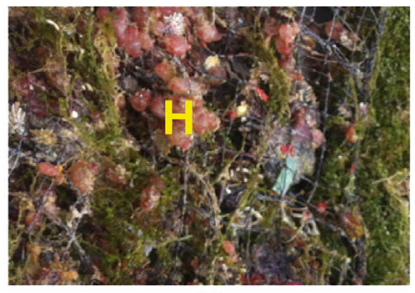

18

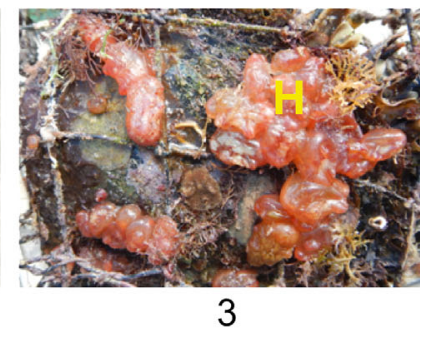

Oct. 2013

May 2012

Nov. 2012

July 2013

Fig. 2. Patterns of change over time of the epibiont colonization on pearl oyster Pinctada margaritifera nets in Mangareva. Numbers indicate the duration (in months) of the colonization by epibionts at each sampling date. Note: Colonization was interrupted in July 2013 after the nets were accidentaly cleaned by the farmer (see 'Materials \& methods'). D: Didemnum sp. H: Herdmania momus

Table 1. Food sources for pearl oysters Pinctada margaritifera and ascidians in ambient water. Concentrations of particulate organic carbon (POC) and nitrogen (PON) and carbon:nitrogen ratio (C:N) for the 2 size classes of POM at the 2 sites and for the different sampling dates $(n=3$, mean $\pm \mathrm{SD})$ are given. -: data excluded because of contamination of the samples

\begin{tabular}{|c|c|c|c|c|c|c|}
\hline \multirow[t]{2}{*}{ Site } & \multicolumn{3}{|c|}{$-\mathrm{POM}<20 \mu \mathrm{m}-$} & \multirow[b]{2}{*}{ PON $\left(\mu g l^{-1}\right)$} & $\mathrm{POM}>20 \mu \mathrm{m}$ & \multirow[b]{2}{*}{$\mathrm{C}: \mathrm{N}$} \\
\hline & PON $\left(\mu g \mathrm{l}^{-1}\right)$ & $\mathrm{POC}\left(\mu \mathrm{g}^{-1}\right)$ & $C: N$ & & POC $\left(\mu g l^{-1}\right)$ & \\
\hline \multicolumn{7}{|l|}{ Mangareva } \\
\hline May 2012 & $7.85 \pm 0.02$ & $36.15 \pm 6.66$ & $6.12 \pm 1.03$ & - & - & - \\
\hline Nov 2012 & $5.71 \pm 2.62$ & $32.42 \pm 10.81$ & $6.97 \pm 1.14$ & $0.02 \pm 0.01$ & $0.11 \pm 0.01$ & $5.86 \pm 1.12$ \\
\hline Oct 2013 & $10.69 \pm 3.46$ & $62.08 \pm 17.45$ & $6.58 \pm 0.66$ & $0.06 \pm 0.03$ & $0.35 \pm 0.15$ & $6.24 \pm 0.56$ \\
\hline \multicolumn{7}{|l|}{ Ahe } \\
\hline May 2013 & $7.98 \pm 1.5$ & $47.63 \pm 13.98$ & $6.87 \pm 0.78$ & $0.25 \pm 0.15$ & $1.12 \pm 0.71$ & $5.26 \pm 0.37$ \\
\hline
\end{tabular}



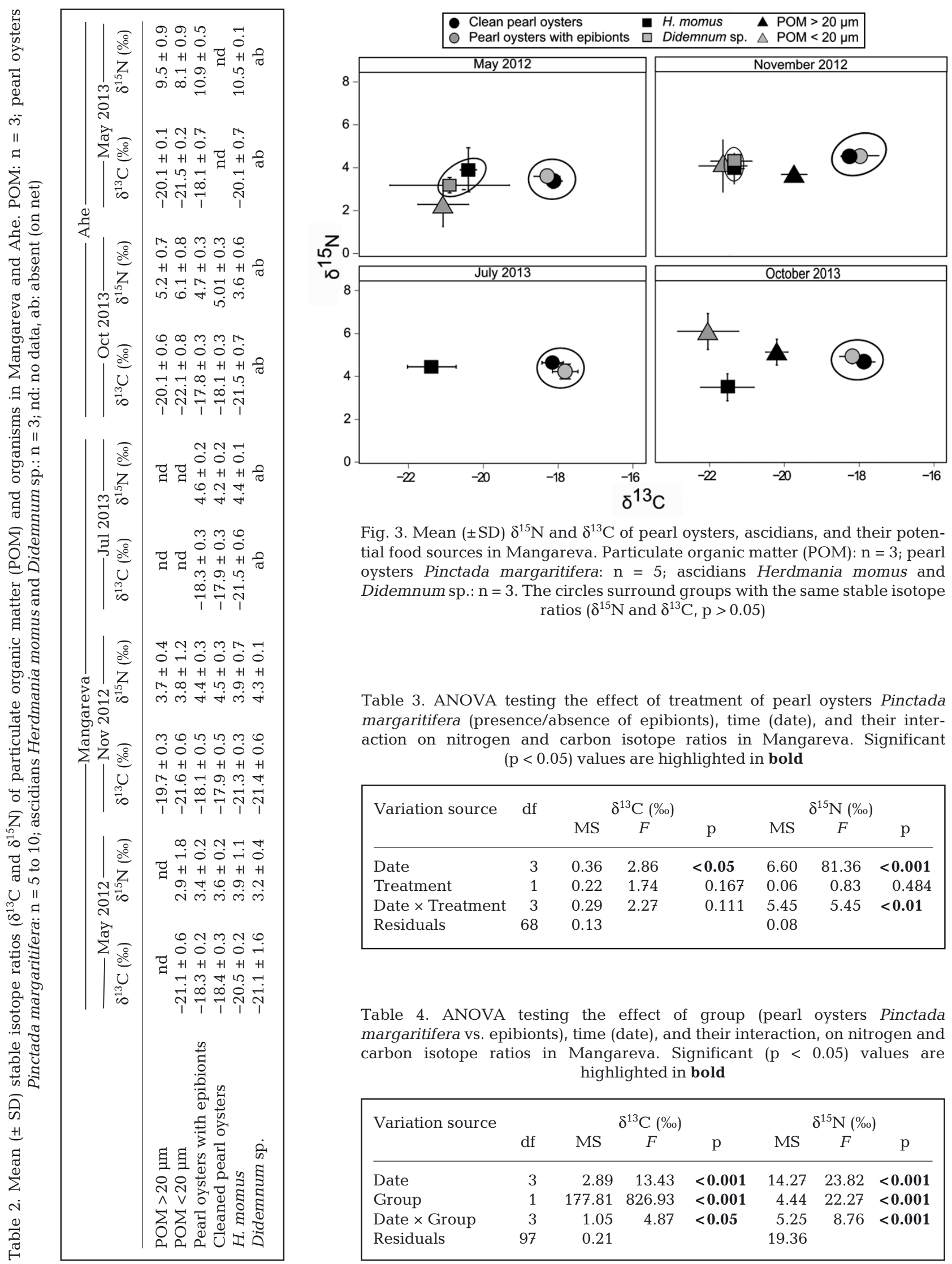

Fig. 3. Mean $( \pm \mathrm{SD}) \delta^{15} \mathrm{~N}$ and $\delta^{13} \mathrm{C}$ of pearl oysters, ascidians, and their potential food sources in Mangareva. Particulate organic matter (POM): $\mathrm{n}=3$; pearl oysters Pinctada margaritifera: $\mathrm{n}=5$; ascidians Herdmania momus and Didemnum sp.: $\mathrm{n}=3$. The circles surround groups with the same stable isotope ratios $\left(\delta^{15} \mathrm{~N}\right.$ and $\left.\delta^{13} \mathrm{C}, \mathrm{p}>0.05\right)$

Table 3. ANOVA testing the effect of treatment of pearl oysters Pinctada margaritifera (presence/absence of epibionts), time (date), and their interaction on nitrogen and carbon isotope ratios in Mangareva. Significant $(\mathrm{p}<0.05)$ values are highlighted in bold

\begin{tabular}{|lrccccccc|}
\hline Variation source & df & \multicolumn{3}{c}{$\delta^{13} \mathrm{C}(\%)$} & & \multicolumn{3}{c|}{$\delta^{15} \mathrm{~N}(\%)$} \\
& & MS & $F$ & $\mathrm{p}$ & $\mathrm{MS}$ & $F$ & $\mathrm{p}$ \\
\hline Date & 3 & 0.36 & 2.86 & $\mathbf{2 0 . 0 5}$ & 6.60 & 81.36 & $<\mathbf{0 . 0 0 1}$ \\
Treatment & 1 & 0.22 & 1.74 & 0.167 & 0.06 & 0.83 & 0.484 \\
Date $\times$ Treatment & 3 & 0.29 & 2.27 & 0.111 & 5.45 & 5.45 & $<\mathbf{0 . 0 1}$ \\
Residuals & 68 & 0.13 & & & 0.08 & & \\
\hline
\end{tabular}

Table 4. ANOVA testing the effect of group (pearl oysters Pinctada margaritifera vs. epibionts), time (date), and their interaction, on nitrogen and carbon isotope ratios in Mangareva. Significant $(p<0.05)$ values are highlighted in bold

\begin{tabular}{|c|c|c|c|c|c|c|c|}
\hline \multirow{2}{*}{ Variation source } & \multirow[b]{2}{*}{$\mathrm{df}$} & \multicolumn{3}{|c|}{$\delta^{13} \mathrm{C}(\%)$} & \multicolumn{3}{|c|}{$\delta^{15} \mathrm{~N}(\%)$} \\
\hline & & MS & F & $\mathrm{p}$ & MS & $F$ & $\mathrm{p}$ \\
\hline Date & 3 & 2.89 & 13.43 & $<0.001$ & 14.27 & 23.82 & $<0.001$ \\
\hline Group & 1 & 177.81 & 826.93 & $<0.001$ & 4.44 & 22.27 & $<0.001$ \\
\hline Date $\times$ Group & 3 & 1.05 & 4.87 & $<0.05$ & 5.25 & 8.76 & $<0.001$ \\
\hline Residuals & 97 & 0.21 & & & 19.36 & & \\
\hline
\end{tabular}


between 3.2 and $4.5 \%$, and their mean $\delta^{13} \mathrm{C}$ for the whole period was $-21 \%$. (Fig. 3, Table 2). During the experiment in Mangareva, interspecific variations in SIRs always remained higher than intraspecific variations, with no significant effect of treatment (presence/absence of epibionts) on $\delta^{13} \mathrm{C}$ and $\delta^{15} \mathrm{~N}$ (Table 3). The interaction Date $\times$ Treatment had a significant effect on $\delta^{15} \mathrm{~N}$, corresponding to a significant increase in values for both groups (Tukey HSD, $\mathrm{p}<0.001$ ) between each month, except between July and November (October $2013>$ July $2013=$ November 2012 > May 2012; Tukey HSD November to July, $p=0.33$ for clean pearl oysters and $p=0.86$ for pearl oysters with epibionts). The interaction of Group and Date had a significant effect on $\delta^{13} \mathrm{C}$ and $\delta^{15} \mathrm{~N}$ (Table 4). Pearl oysters had higher $\delta^{13} \mathrm{C}$ compared with ascidians for the 4 dates (Tukey HSD, $\mathrm{p}<0.001$ ), and higher $\delta^{15} \mathrm{~N}$ in October 2013 (Tukey HSD, p < 0.001). As observed in Mangareva, ascidians from Ahe were isotopically depleted in carbon compared to pearl oysters, while their $\delta^{15} \mathrm{~N}$ values did not significantly differ (Table 2). $\delta^{15} \mathrm{~N}$ values of POM, ascidians, and pearl oysters were higher in Ahe than in Mangareva.

\section{Ascidian diet}

During our experiments, 3 groups of phytoplankton were identified in the ambient water of Mangareva lagoon using flow cytometry (Fig. 4). Cyanobacteria were characterized by their orange fluorescence (phycoerythrine) and their small size. Picoeukaryotes were bigger than cyanobacteria and without orange fluorescence. Cyanobacteria and picoeukaryotes belong to the picophytoplankton, while the third group, which was composed of larger cells $(>3 \mu \mathrm{m})$, correspond to nanophytoplankton.

\section{CR and RE}

In May and November 2012, ascidians retained the 3 groups of phytoplankton with an efficiency of $70 \%$ (Table 5). In October 2013, RE of $H$. momus for the 3 phytoplanktonic groups was lower $(<55 \%$, Table 5$)$. $\mathrm{RE}$ and $\mathrm{CR}$ of ascidians did not vary according to the phytoplankton com-

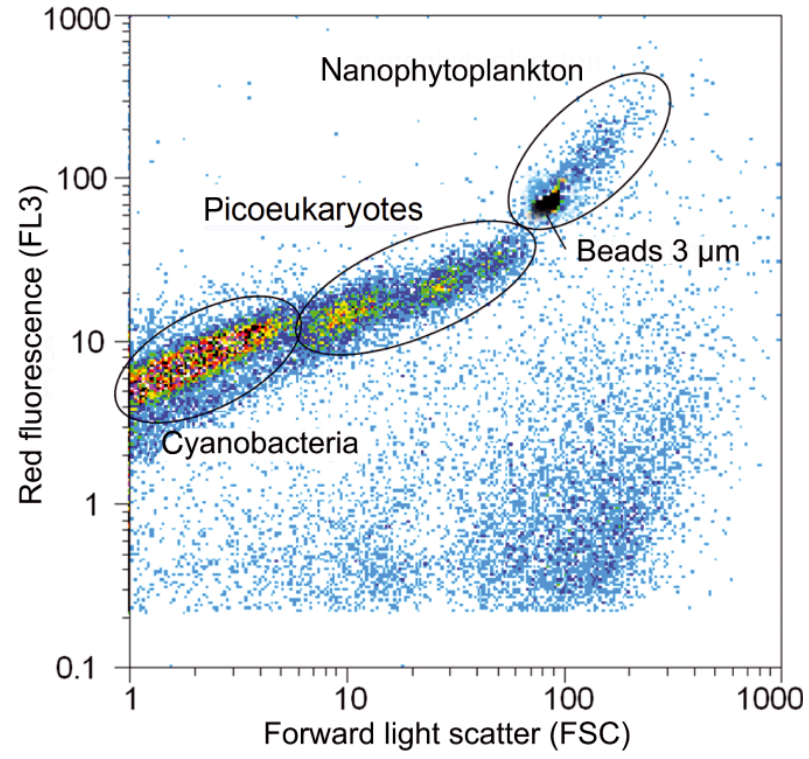

Fig. 4. Cytogram of ambient seawater showing the discrimination of cyanobacteria, picoeukaryotes, and nanophytoplankton. Standard beads $(3 \mu \mathrm{m})$ were used to identify the particle size

munity structure (i.e. concentration of the different groups) in the environment (Table 5). For H. momus, $\mathrm{RE}$ and CR were identical for the 3 groups of phytoplankton, while CR of Didemnum sp. was lower for nanophytoplankton than for picophytoplankton (Tukey HSD). CR of the 2 ascidian species varied between 0.04 and $0.16 \mathrm{l} \mathrm{h}^{-1} \mathrm{~g}^{-1}$ dry weight for the 3 food sources.
Table 5. Phytoplankton concentration in ambient water and ascidian filtration in Mangareva. Clearance rate (CR) and retention efficiency (RE) for the different sampling dates are given as mean \pm SD. Cyano: cyanobacteria (size $<3 \mu \mathrm{m}$ ); Pico: picophytoplankton (size $<3 \mu \mathrm{m}$ ), Nano: nanophytoplankton (3-20 $\mu \mathrm{m})$. -: not applicable; species not present on the net

\begin{tabular}{|c|c|c|c|c|c|}
\hline \multirow{2}{*}{\multicolumn{2}{|c|}{$\begin{array}{c}\text { Ambient water } \\
\left(10^{7} \text { cells } 1^{-1}\right)\end{array}$}} & \multicolumn{2}{|c|}{ Didemnum sp. } & \multicolumn{2}{|c|}{ Herdmania momus } \\
\hline & & $\operatorname{CR}\left(1 \mathrm{~h}^{-1} \mathrm{~g}^{-1}\right)$ & RE (\%) & $\operatorname{CR}\left(1 \mathrm{~h}^{-1} \mathrm{~g}^{-1}\right)$ & RE (\%) \\
\hline \multicolumn{6}{|c|}{ May $2012(n=6)$} \\
\hline Cyano & 3.92 & $0.08 \pm 0.02$ & $76.70 \pm 14.82$ & - & - \\
\hline Pico & 1.35 & $0.06 \pm 0.02$ & $69.14 \pm 18.37$ & - & - \\
\hline Nano & 0.20 & $0.04 \pm 0.02$ & $70.15 \pm 15.67$ & - & - \\
\hline \multicolumn{6}{|c|}{ Nov $2012(n=3)$} \\
\hline Cyano & 6.77 & $0.12 \pm 0.02$ & $87.06 \pm 14.33$ & $0.16 \pm 0.07$ & $78.42 \pm 15.00$ \\
\hline Pico & 0.40 & $0.11 \pm 0.02$ & $85.16 \pm 16.19$ & $0.16 \pm 0.07$ & $82.58 \pm 12.20$ \\
\hline Nano & 0.12 & $0.07 \pm 0.01$ & $84.18 \pm 5.23$ & $0.14 \pm 0.06$ & $79.79 \pm 15.80$ \\
\hline \multicolumn{6}{|c|}{ Oct $2013(n=6)$} \\
\hline Cyano & 6.84 & & & $0.04 \pm 0.01$ & $48.11 \pm 15.47$ \\
\hline Pico & 0.83 & & & $0.05 \pm 0.02$ & $54.01 \pm 14.43$ \\
\hline Nano & 0.28 & & & $0.05 \pm 0.02$ & $48.98 \pm 11.88$ \\
\hline
\end{tabular}



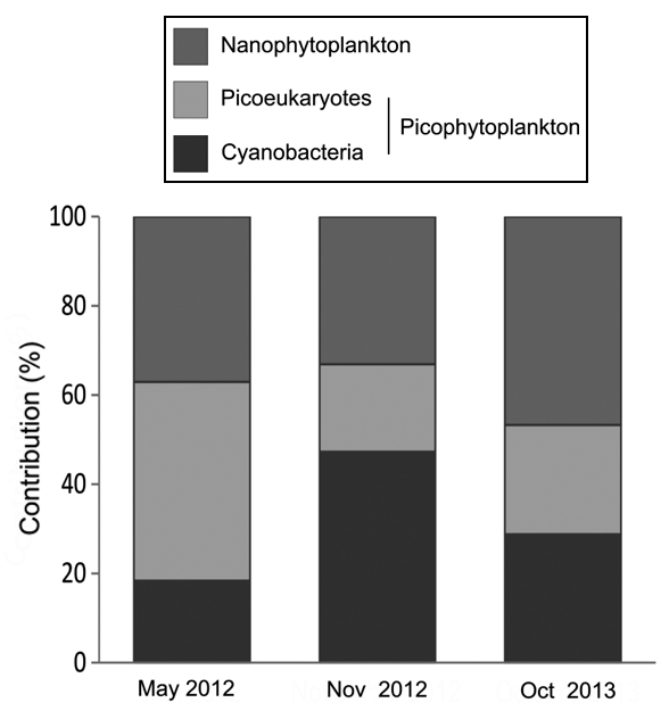

Fig. 5. Proportion of the 3 groups of phytoplankton in ambient seawater, expressed as a percentage of carbon biomass, for the 3 dates of the experiment

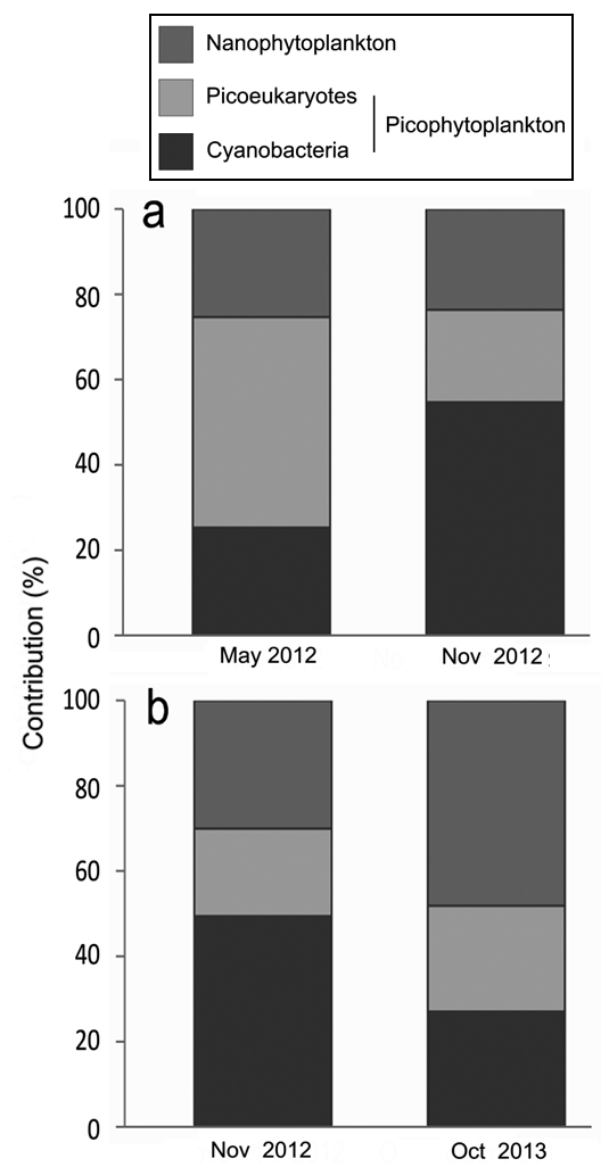

Fig. 6. Proportion of carbon retained by (a) Didemnum sp. and (b) Herdmania momus according to the different groups of phytoplankton for each sampling date

\section{Origin of carbon retained}

On the 3 sampling dates, the picophytoplankton (cyanobacteria + picoeukaryotes) represented $60 \%$ of the total carbon biomass of phytoplankton identified in the ambient water (Fig. 5). The contribution of cyanobacteria to the carbon biomass doubled between May and November 2012, and represented $50 \%$ of the total carbon biomass in November 2012 (Fig. 5). The contribution of each phytoplankton group to the carbon retained by the ascidians (Fig. 6) varied in the same way as the proportion of these groups in the ambient water (Fig. 5). Picophytoplankton always represented at least $70 \%$ of the carbon retained by Didemnum sp., while nanophytoplankton could represent up to $50 \%$ of the diet of $H$. momus when nanophytoplankton concentration increased in the ambient water (October 2013).

\section{DISCUSSION}

Most epibiont species are filter feeders and may compete for food with reared bivalves if their diets overlap. Such competition may reduce the performance of bivalves and greatly reduce the commercial yield, yet few, and generally only inconclusive reports (Claereboudt et al. 1994, Pit \& Southgate 2003), have described this competition. This study aimed to provide first measurement of the interactions for food between reared pearl oysters and their main epibionts. We first characterized the isotopic signature of pearl oysters, ascidians, and their potential food source (POM) and then conducted a feeding experiment under natural conditions to document the use of available trophic resources by ascidians.

\section{Intra- and interspecific variations in SIRs}

Intraspecific variability in diets of organisms can occur as a response to interspecific competition for food (Haken \& Batzli 1996). Using stable isotopes, Yakovis et al. (2012) showed that the diet of the mussel Modiolus modiolus is not modified by the presence of ascidians, and concluded that no competition for food occurs between these organisms. Here, we showed that pearl oysters, either in the presence or absence of epibionts, exhibited the same isotopic composition during 20 mo of biofouling development. This suggests that the development of biofouling did not affect the diet of the pearl 
oysters, although the weight of epibionts could represent 30 to $40 \%$ of the pearl oysters' weight on a net. This finding is confirmed by measurements of pearl oyster growth rates, which were similar in the presence or absence of epibionts (Lacoste et al. 2014b).

Organisms with similar diets generally show similar carbon and nitrogen SIRs (Fry et al. 1987, Riera et al. 2002). Because the same mixture is brought by water movement to suspension feeders living near each other, observed differences in isotopic composition reveal differences in the way that suspension feeders deal with food quality and quantity (Dubois \& Colombo 2014). According to the recorded values of nitrogen SIRs in our study, we confirmed that pearl oysters and ascidians were positioned at the same trophic level. However, the constant difference of their $\delta^{13} \mathrm{C}$ values revealed that they feed on different food sources and/or in different proportions. On all sampling dates, pearl oysters were ${ }^{13} \mathrm{C}$-enriched compared to ascidians. Several studies have shown similar results, with $\delta^{13} \mathrm{C}$ of bivalves higher than that of ascidians (Dubois et al. 2007, Kang et al. 2009, Yakovis et al. 2012). Kang et al. (2009) attributed these differences to a preferential utilization of pico- and nanophytoplankton by ascidians, while bivalves (Pacific oysters Crassostrea gigas) used a greater proportion of microphytoplankton, particularly diatoms with larger sizes and higher $\delta^{13} \mathrm{C}$ values. The differences of SIR between pearl oysters and ascidians could thus be explained by a differential use of phytoplanktonic food sources, according to particle size. These differences are likely related to differences in sorting abilities between bivalves and ascidians, with bivalves being well known for their ability to sort and select food particles, in contrast to ascidians (Ward \& Shumway 2004, Riisgård \& Larsen 2010). Even if there is a diet overlap for some food items, the similar growth rate measured for pearl oysters in the presence or absence of epibionts (Lacoste et al. 2014b) indicated that biofouling does not prevent pearl oysters from accessing sufficient food resources to support their growth.

\section{Carbon origin and $\delta^{13} \mathrm{C}$ value}

During feeding experiments using flow cytometry and microscopic observations, Fournier et al. (2012) showed that nanophytoplankton represents $90 \%$ of the carbon ingested by pearl oysters, whereas pico- phytoplankton is barely retained. Using different techniques (laboratory, gut contents, HPLC), Pouvreau et al. (1999) and Loret et al. (2000) also showed that pearl oysters more efficiently retain particles between 5 and $60 \mu \mathrm{m}$ than particles smaller than $2 \mu \mathrm{m}$. Conversely, the feeding experiments realized during our study showed that the main source of carbon for ascidians originated from small particles (picophytoplankton $<3 \mu \mathrm{m}$ ) and occasionally from nanophytoplankton (Herdmania momus). Our results also showed that the small POM $(<20 \mu \mathrm{m})$ was depleted in ${ }^{13} \mathrm{C}$ compared with POM $>20 \mu \mathrm{m}$, which is in agreement with the observation that small planktonic particles are consistently depleted in ${ }^{13} \mathrm{C}$ compared to large particles (Rau et al. 1990, Rolff 2000). The origin of carbon assimilated by a living organism could be reflected by its carbon SIR (Peterson \& Fry 1987). The higher $\delta^{13} \mathrm{C}$ values of pearl oysters would thus indicate a higher assimilation of carbon from larger particles compared with ascidians, whose lower $\delta^{13} \mathrm{C}$ should be more strongly influenced by picoplanktonic particles which represent the larger fraction of plankton in the ambient water. Future studies should try to measure the SIR of additional fractions of POM (e.g. particle size of $2-20 \mu \mathrm{m}$ ) that would allow defining more precisely the relationships between filter feeders and prey particles.

The first feeding experiments realized in this study provided some insights concerning the food source exploitation by the ascidians $H$. momus and Didemnum sp. fed with a natural mix of phytoplankton. The contribution of each plankton group to the carbon retained by ascidians reflected the proportion represented by each group in the environment (in terms of carbon biomass), and the RE and $\mathrm{CR}$ of ascidians did not differ significantly among the 3 groups of phytoplankton, except CR of Didemnum sp., which differed between cyanobacteria and nanoeukaryotes. This confirms the general observation that most ascidians do not select food particles (Stuart \& Klumpp 1984, Ribes et al. 1998). However, the difference in $\mathrm{CR}$ of Didemnum sp., which indicated a higher CR for cyanobacteria than for nanoeukaryotes, is a surprising finding and is difficult to interpret. This result is even more surprising since no specific organ has been described for ascidians that allows for the sorting of particles (Riisgård \& Larsen 2010). However, the same result was obtained on 2 different dates. Given the poorly known ecology of Didemnum sp., this result will require further investigations and additional experiments. 


\section{Spatio-temporal variations in food sources}

$\mathrm{C}: \mathrm{N}$ ratios of POM for the 2 sites (5.26 to 6.97) indicated that phytoplankton was the main component of this compartment (Savoye et al. 2003). Carbon biomass of POM in ambient water was mainly attributed to particles $<20 \mu \mathrm{m}$, and particularly to picophytoplankton $(<2 \mu \mathrm{m})$. The $\delta^{13} \mathrm{C}$ values of filter feeders did not show any difference between the 2 sites, while the $\delta^{15} \mathrm{~N}$ values of POM, pearl oysters, and ascidians were higher in Ahe than in Mangareva. This difference could be attributed to the geographical location of these islands ( $8^{\circ}$ latitude difference) and to their geomorphological differences, which induce different residence times of water and probably of material recycling, especially nitrogen. Differences of nitrogen SIRs in POM are commonly attributed to a different use of nitrogen by primary producers at the base of the food web due to a difference in the nitrogen origin and/or to a differential composition of POM (Lourey et al. 2003, Sigman et al. 2005). The origin of the higher nitrogen SIRs in Ahe could thus be due to the utilization of nitrogen from benthic mineralization processes $\left(\mathrm{NO}^{3-}\right)$ or to the presence of high amounts of detritus in POM (e.g. fecal pellets). An important benthic mineralization of organic material has been recorded in the under rearing structures, which may provide nitrate to the pelagic system (Gaertner-Mazouni et al. 2012). Pagano et al. (2012) also highlighted the importance of detritus (fecal pellets, organic flocs) and the microbial loop in the trophic network of Ahe, which may give rise to intensive microbial biofilm resuspension (Saint-Béat et al. 2014). Because comparable information is not available for Mangareva (e.g. physicochemical parameters, POM composition), we cannot go further with these hypotheses.

The temporal constancy of POM SIRs in Mangareva indicated the relative stability of the trophic conditions over the year. This is the general trend observed for French Polynesian lagoons (Torréton \& Dufour 1996, Delesalle et al. 2001). However, we should point out the increase in $\delta^{15} \mathrm{~N}$ values in October 2013, which were close to those observed in Ahe. This increase in $\delta^{15} \mathrm{~N}$ occurred concurrent with increased levels of POC and PON in the water column, indicating enrichment during this period. In temperate areas, blooms are characterized by the progressive nitrogen enrichment of phytoplankton (thus increasing its $\delta^{15} \mathrm{~N}$ value) as the nutrient concentration decreases in the water column (Savoye et al. 2003, Raimbault et al. 2008). At the same time, the POM accumulates heavy nitrogen from zooplankton fecal pellets. This process could explain the increased $\delta^{15} \mathrm{~N}$ observed in Mangareva in October 2013 following an enrichment of the water column. Unfortunately, insufficient information concerning the POM composition is available for this period. However, large quantities of zooplankton (e.g. copepods) were observed during the sampling period in October 2013 (E. Lacoste pers. obs.), suggesting the development of these communities.

\section{CONCLUSION}

This is the first study to simultaneously use stable isotopes and flow cytometry, and has provided new insights on the interactions for food between pearl oysters and ascidians in 2 lagoons of French Polynesia. The results confirmed the non-selectivity for food by ascidians, whose carbon source mainly originated from picophytoplankton, the dominant group in the oligotrophic waters of French Polynesia. Conversely, the higher $\delta^{13} \mathrm{C}$ signature of pearl oysters compared with ascidians indicated that carbon sources of pearl oysters originated from larger particles (nano- and microphytoplankton). While interspecific competition may occur between pearl oysters and ascidians for nanophytoplankton, the diet of Pinctada margaritifera was not modified by the presence of epibionts (ascidians plus other invertebrates).

Further experiments should strengthen the observations and conclusions from this study. While some logistical constraints restricted our sample sizes, future studies should include more nets per treatment and explore the interactions for food between pearl oysters and other species of epibionts (e.g. bivalves, sponges). Moreover, supplementary data on the biology of epibionts will allow us to evaluate more precisely the impact of pearl farming on the whole ecosystem (Lacoste \& Gaertner-Mazouni 2015). We showed here that ascidians had no impact on the food availability for pearl oysters, but this finding should be extended to a larger scale. Woods et al. (2012) and Comeau et al. (2015) showed that ascidians contribute greatly to the global depletion of phytoplankton at the farm scale in mussel culture. For the majority of biofouling species, there is a paucity of information on metabolic processes and activities that could be factored into carrying capacity models. To achieve sustainable production, reliable estimation of carrying capacity of farming environments is required, and further studies should thus characterize the metabolic activity of epibionts under different fouling scenarios (e.g. different densities, species, scales). 
Acknowledgements. This study received financial support from the Agence Nationale de la Recherche within the framework of the program AGROBIOSPHERE (ANR-11AGRO-006). É.L. was supported by a doctoral fellowship from the Ministère de l'Enseignement Supérieur et de la Recherche at the University of French Polynesia. We are grateful to the pearl oyster farmers (Dominique Devaux and Sejii Nakasai) for their help in the field. We also thank the 4 anonymous reviewers for their help in improving the manuscript.

\section{LITERATURE CITED}

Adams CM, Shumway SE, Whitlatch RB, Getchis T (2011) Biofouling in marine molluscan shellfish aquaculture: a survey assessing the business and economic implications of mitigation. J World Aquacult Soc 42:242-252

> Arakawa K (1990) Competitors and fouling organisms in the hanging culture of the Pacific oyster, Crassostrea gigas (Thunberg). Mar Freshw Behav Physiol 17:67-94

> Charpy L, Blanchot J (1998) Photosynthetic picoplankton in French Polynesian atoll lagoons: estimation of taxa contribution to biomass and production by flow cytometry. Mar Ecol Prog Ser 162:57-70

> Claereboudt MR, Bureau D, Côté J, Himmelman JH (1994) Fouling development and its effect on the growth of juvenile giant scallops (Placopecten magellanicus) in suspended culture. Aquaculture 121:327-342

Comeau LA, Filgueira R, Guyondet T, Sonier R (2015) The impact of invasive tunicates on the demand for phytoplankton in longline mussel farms. Aquaculture 441: 95-105

> Coughlan J (1969) The estimation of filtering rate from the clearance of suspensions. Mar Biol 2:356-358

Cranford P, Dowd M, Grant J, Hargrave B, McGladdery S (2003) Ecosystem level effects of marine bivalve aquaculture. Can Tech Rep Fish Aquat Sci 2450:51-95

> Daigle R, Herbinger C (2009) Ecological interactions between the vase tunicate (Ciona intestinalis) and the farmed blue mussel (Mytilus edulis) in Nova Scotia, Canada. Aquat Invas 4:177-187

Decottignies P, Beninger PG, Rincé Y, Riera P, Rince Y (2007) Trophic interactions between two introduced suspension-feeders, Crepidula fornicata and Crassostrea gigas, are influenced by seasonal effects and qualitative selection capacity. J Exp Mar Biol Ecol 342:231-241

> Delesalle B, Sakka A, Legendre L, Pagès J, Charpy L, Loret P (2001) Phytoplankton of Takapoto Atoll (Tuamotu Archipelago, French Polynesia): time and space variability of biomass, primary production and composition over 24 years. Aquat Living Resour 14:175-182

Dubois SF, Colombo F (2014) How picky can you be? Temporal variations in trophic niches of co-occurring suspension-feeding species. Food Webs 1:1-9

Dubois S, Orvain F, Marin-Léal JC, Ropert M, Lefebvre S (2007) Small-scale spatial variability of food partitioning between cultivated oysters and associated suspensionfeeding species, as revealed by stable isotopes. Mar Ecol Prog Ser 336:151-160

Dupuy C, Bouvy M, Charpy L, Fournier J and others (2009) Planktonic compartment of Ahe Atoll (Tuamotu Archipelago, French Polynesia): potential preys for pearl oyster Pinctada margaritifera. $11^{\text {th }}$ Pacific Science Intercongress, Tahiti. http://webistem.com/psi2009/output_ directory/cd1/Data/articles/000512.pdf
Fitridge I, Dempster T, Guenther J, de Nys R (2012) The impact and control of biofouling in marine aquaculture: a review. Biofouling 28:649-669

Fournier J, Dupuy C, Bouvy M, Couraudon-Reale M and others (2012) Pearl oysters Pinctada margaritifera grazing on natural plankton in Ahe atoll lagoon (Tuamotu archipelago, French Polynesia). Mar Pollut Bull 65: 490-499

Fry B (2006) Stable isotope ecology. Springer, Heidelberg

Fry B, Macko S, Zieman J (1987) Review of stable isotopic investigations of food webs in seagrass meadows. Fla Mar Res Publ 42:189-209

> Gaertner-Mazouni N, Lacoste E, Bodoy A, Peacock L and others (2012) Nutrient fluxes between water column and sediments: potential influence of the pearl oyster culture. Mar Pollut Bull 65:500-505

> Guenther J, de Nys R (2006) Differential community development of fouling species on the pearl oysters Pinctada fucata, Pteria penguin and Pteria chinensis (Bivalvia, Pteriidae). Biofouling 22:151-159

Haken AE, Batzli GO (1996) Effects of availability of food and interspecific competition on diets of prairie voles (Microtus ochrogaster). J Mammal 77:315-324

Herr DG (1986) On the history of ANOVA in unbalanced, factorial designs: the first 30 years. Am Stat 40:265-270

Kang CK, Choy EJ, Hur YB, Myeong JI (2009) Isotopic evidence of particle size-dependent food partitioning in cocultured sea squirt Halocynthia roretzi and Pacific oyster Crassostrea gigas. Aquat Biol 6:289-302

Lacoste E (2014) Interactions entre les huitres perlières en élevage (Pinctada margaritifera) et les communautés d'épibiontes, et influence de l'association sur les flux de matière dans les lagons de Polynésie française. $\mathrm{PhD}$ thesis, Université de Polynésie Française, Tahiti

> Lacoste E, Gaertner-Mazouni N (2015) Biofouling impact on production and ecosystem functioning: a review for bivalve aquaculture. Rev Aquacult 7:187-196

> Lacoste E, Gueguen Y, Le Moullac G, Koua MS, GaertnerMazouni N (2014a) Influence of farmed pearl oysters and associated biofouling communities on nutrient regeneration in lagoons of French Polynesia. Aquacult Environ Interact 5:209-219

- Lacoste E, Le Moullac G, Levy P, Gueguen Y, GaertnerMazouni N (2014b) Biofouling development and its effect on growth and reproduction of the pearl oyster Pinctada margaritifera, in suspended cultures of French Polynesia. Aquaculture 434:18-26

> Lefebvre S, Marín Leal JC, Dubois S, Orvain F and others (2009) Seasonal dynamics of trophic relationships among co-occurring suspension-feeders in two shellfish culture dominated ecosystems. Estuar Coast Shelf Sci 82: 415-425

> Lesser MP, Shumway SE, Cucci T, Smith J (1992) Impact of fouling organisms on mussel rope culture: interspecific competition for food among suspension-feeding invertebrates. J Exp Mar Biol Ecol 165:91-102

Lopez DA, Riquelme V, Gonzales ML (2000) The effects of epibionts and predators on the growth and mortality rates of Argopecten purpuratus cultures in southern Chile. Aquacult Int 8:431-442

- Loret P, Pastoureaud A, Bacher C, Delesalle B (2000) Phytoplankton composition and selective feeding of the pearl oyster Pinctada margaritifera in the Takapoto lagoon (Tuamotu Archipelago, French Polynesia): in situ study using optical microscopy and HPLC pigment analysis. 
Mar Ecol Prog Ser 199:55-67

Lourey MJ, Trull TW, Sigman DM (2003) Sensitivity of $\delta 15$ $\mathrm{N}$ of nitrate, surface suspended and deep sinking particulate nitrogen to seasonal nitrate depletion in the Southern Ocean. Global Biogeochem Cycles 17:1081

Mazouni N, Gaertner JC, Deslous-Paoli JM (2001) Composition of biofouling communities on suspended oyster cultures: an in situ study of their interactions with the water column. Mar Ecol Prog Ser 214:93-102

- Miranda NA, Perissinotto R (2012) Stable isotope evidence for dietary overlap between alien and native gastropods in coastal lakes of northern KwaZulu-Natal, South Africa. PLoS ONE 7:e31897

Mook DH (1981) Removal of suspended particles by fouling communities. Mar Ecol Prog Ser 5:279-281

Pagano M, Sagarra P, Champalbert G, Bouvy M, Dupuy C, Thomas Y, Charpy L (2012) Metazooplankton communities in the Ahe atoll lagoon (Tuamotu Archipelago, French Polynesia): spatio-temporal variations and trophic relationships. Mar Pollut Bull 65:538-548

Petersen JK (2007) Ascidian suspension feeding. J Exp Mar Biol Ecol 342:127-137

> Peterson BJ, Fry B (1987) Stable isotopes in ecosystem studies. Annu Rev Ecol Syst 18:293-320

$>$ Pit JH, Southgate PC (2003) Fouling and predation; How do they affect growth and survival of the blacklip pearl oyster, Pinctada margaritifera, during nursery culture? Aquacult Int 11:545-555

Pouvreau S, Jonquières G, Buestel D (1999) Filtration by the pearl oyster, Pinctada margaritifera, under conditions of low seston load and small particle size in a tropical lagoon habitat. Aquaculture 176:295-314

Raimbault P, Garcia N, Cerrutti F (2008) Distribution of inorganic and organic nutrients in the South Pacific Ocean. Evidence for long-term accumulation of organic matter in nitrogen-depleted waters. Biogeosciences 5: 281-298

Rau GH, Teyssie JL, Rassoulzagedan F, Fowler SW (1990) ${ }^{13} \mathrm{C} /{ }^{12} \mathrm{C}$ and ${ }^{15} \mathrm{~N} /{ }^{14} \mathrm{~N}$ variations among size-fractionated marine particles: implications for their origin and trophic relationships. Mar Ecol Prog Ser 59:33-38

Ribes M, Coma R, Gili JM (1998) Seasonal variation of in situ feeding rates by the temperate ascidian Halocynthia papillosa. Mar Ecol Prog Ser 175:201-213

Riera P, Stal LJ, Nieuwenhuize J (2002) $\delta^{13} \mathrm{C}$ versus $\delta^{15} \mathrm{~N}$ of co-occurring molluscs within a community dominated by Crassostrea gigas and Crepidula fornicata (Oosterschelde, The Netherlands). Mar Ecol Prog Ser 240: 291-295

Riisgård HU, Larsen PS (2010) Particle capture mechanisms in suspension-feeding invertebrates. Mar Ecol Prog Ser 418:255-293

Rius M, Heasman KG, McQuaid CD (2011) Long-term coexistence of non-indigenous species in aquaculture facil-

Editorial responsibility: Philippe Archambault,

Rimouski, Québec, Canada ities. Mar Pollut Bull 62:2395-2403

Rolff C (2000) Seasonal variation in $\delta^{13} \mathrm{C}$ and $\delta^{15} \mathrm{~N}$ of sizefractionated plankton at a coastal station in the northern Baltic proper. Mar Ecol Prog Ser 203:47-65

> Saint-Béat B, Dupuy C, Agogué H, Carpentier A and others (2014) How does the resuspension of the biofilm alter the functioning of the benthos-pelagos coupled food web of a bare mudflat in Marennes-Oléron Bay (NE Atlantic)? J Sea Res 92:144-157

Savoye N, Aminot A, Tréguer P, Fontugne M, Naulet N, Kérouel R (2003) Dynamics of particulate organic matter $\delta^{15} \mathrm{~N}$ and $\delta^{13} \mathrm{C}$ during spring phytoplankton blooms in a macrotidal ecosystem (Bay of Seine, France). Mar Ecol Prog Ser 255:27-41

> Sievers M, Fitridge I, Dempster T, Keough MJ (2013) Biofouling leads to reduced shell growth and flesh weight in the cultured mussel Mytilus galloprovincialis. Biofouling 29:97-107

Sigman DM, Granger J, DiFiore PJ, Lehmann MM, Ho R, Cane G, van Geen A (2005) Coupled nitrogen and oxygen isotope measurements of nitrate along the eastern North Pacific margin. Global Biogeochem Cycles 19: GB4022, doi:10.1029/2005GB002458

Stuart V, Klumpp DW (1984) Evidence for food-resource partitioning by kelp-bed filter feeders. Mar Ecol Prog Ser 16:27-37

Talvard C (2015) Bilan, La perle en 2013. Points forts de la Polynésie française. Institut de la statistique de Polynésie française. www.ispf.pf/docs/default-source/publi-pf-bilanset-etudes/pf-bilan-01-2015-perle-2013.pdf?sfvrsn=4

Topçu NE, Pérez T, Grégori G, Harmelin-Vivien M (2010) In situ investigation of Spongia officinalis (Demospongiae) particle feeding: coupling flow cytometry and stable isotope analysis. J Exp Mar Biol Ecol 389:61-69

> Torréton JP, Dufour P (1996) Temporal and spatial stability of bacterioplankton biomass and productivity in an atoll lagoon. Aquat Microb Ecol 11:251-261

- Ward JE, Shumway SE (2004) Separating the grain from the chaff: particle selection in suspension- and deposit-feeding bivalves. J Exp Mar Biol Ecol 300:83-130

Willemsen PR (2005) Biofouling in European aquaculture: Is there an easy solution? Eur Aquacult Soc Spec Publ 35: 82-87.www.crabproject.com/client/files/Paper_Willemsen. pdf

> Woods CM, Floerl O, Hayden BJ (2012) Biofouling on Greenshell ${ }^{\mathrm{TM}}$ mussel (Perna canaliculus) farms: a preliminary assessment and potential implications for sustainable aquaculture practices. Aquacult Int 20: $537-557$

Yakovis EL, Artemieva AV, Fokin MV, Varfolomeeva MA (2012) Intraspecific variation in stable isotope signatures indicates no small-scale feeding interference between a horse mussel and an ascidian. Mar Ecol Prog Ser 467: $113-120$

Submitted: May 22, 2015; Accepted: October 22, 2015 Proofs received from author(s): January 6, 2016 